\title{
Use of otolith strontium:calcium and zinc:calcium ratios as an indicator of the habitat of Percophis brasiliensis Quoy \& Gaimard, 1825 in the southwestern Atlantic Ocean
}

\author{
Esteban Avigliano ${ }^{1}$, Margarita B. Saez ${ }^{2}$, Rita Rico² and Alejandra V. Volpedo ${ }^{1}$
}

We evaluate the simultaneous use of $\mathrm{Sr}: \mathrm{Ca}$ and $\mathrm{Zn}$ : Ca ratios of the sagitta otolith as a potential indicator of the habitat of Percophis brasiliensis along a latitudinal gradient in the southwestern Atlantic Ocean $\left(34-42^{\circ} \mathrm{S}\right.$ and $\left.51-67^{\circ} \mathrm{W}\right)$, in order to reliably identify fish stocks. Fish were collected in three sampling sites: Argentine-Uruguayan Common Fishing Zone (AUCFZ), El Rincón (ER) and San Matías Gulf (SMG). The otolith Sr:Ca and Zn:Ca ratios were determined by ICP-OES and EDTA volumetric method. The otolith Sr:Ca ratio was similar in the three sampling sites, while the $\mathrm{Zn}$ :Ca ratio was significantly higher in AUCFZ than in ER and SMG for all age groups. The discriminant analysis showed an association between the otolith Sr:Ca and Zn:Ca ratios from ER and SMG. Present results suggest the potential occurrence of two fish stocks of $P$. brasiliensis in the study area.

Evaluamos el uso simultáneo de las relaciones Sr:Ca y Zn:Ca de los otolitos sagittae como un potencial indicador de hábitat de Percophis brasiliensis a lo largo de un gradiente longitudinal el Atlántico sudoccidental $\left(34-42^{\circ} \mathrm{S}-51-67^{\circ} \mathrm{W}\right) \mathrm{con}$ el fin de contribuir a la identificación de los stocks pesqueros. Los peces fueron capturados en tres sitios de muestreo: Zona Común de Pesca Argentina-Uruguaya (ZCPAU), El Rincón (ER) y el Golfo San Matías (GSM). Las relaciones Sr:Ca y $\mathrm{Zn:Ca}$ se determinaron por ICP-OES y por titulación con EDTA. La relación Sr:Ca fue similar en los tres sitios de muestreo. La relación Zn:Ca fue mayor en la ZCPAU que en las demás areas (ER y GSM) para todos los rangos de edad. El análisis discriminante mostró una asociación entre las relaciones Sr:Ca y Zn:Ca de ER y GSM. Los resultados de este trabajo sugieren la presencia de al menos dos stocks de P. brasiliensis en el aérea de estudio.

Keywords: Argentina, Brazilian flathead, Fish stock, Microchemistry, Percophidae.

\section{Introduction}

Fish otoliths are complex polycrystalline structures, composed of trace elements and calcium carbonate crystallized as aragonite $(96 \%)$ in a protein matrix and small quantities of other minerals (Campana, 1999). These structures are placed in the inner ear of fish and are involved in hearing and maintenance of equilibrium (Popper \& Zhongmin, 2000). The concentration of the elements deposited in the otoliths, including strontium ( $\mathrm{Sr}$ ) and zinc (Zn), may be largely affected by the chemical composition of water, and secondarily by temperature (Campana, 1999; Wells et al., 2003; Ranaldi \& Gagnon, 2008). In particular, the concentration of $\mathrm{Sr}$ in the otoliths of anadromous and freshwater species was found to be positively correlated with water salinity (e.g., Kraus \& Secor, 2004; Sturrock et al., 2012; Avigliano \& Volpedo,
2013). However, the relationship between the otolith $\mathrm{Sr}$ and salinity tends to be weak and remains unclear for marine species (Brown \& Severin, 2009; Sturrock et al., 2012). The fact that the incorporation of Sr into the otolith is affected by the environment makes this element a useful tool to study fish displacements and identify fish stocks (Secor et al., 1995; Zlokovitz et al., 2003; Kraus \& Secor, 2004; Schuchert et al., 2010; Tabouret et al., 2010; Avigliano \& Volpedo, 2013; Avigliano et al., 2013). On the other hand, the concentration of $\mathrm{Zn}$ in the otoliths may be closely associated with fish diet. For this reason, $\mathrm{Zn}$ is a potential habitat indicator (Ranaldi \& Gagnon, 2008), especially when the otolith $\mathrm{Sr}: \mathrm{Ca}$ ratio proves to be inadequate, as for some coastal marine species (Brown \& Severin, 2009; Sturrock et al. 2012). Unlike the otolith $\mathrm{Sr}: \mathrm{Ca}$ ratio, the $\mathrm{Zn}: \mathrm{Ca}$ ratio decreases with water salinity (McCulloch et al., 2005).

${ }^{1}$ Instituto de Investigaciones en Producción Animal (INPA-CONICET), Facultad de Ciencias Veterinarias, Universidad de Buenos Aires. Av. Chorroarín 280. C1427CWO Buenos Aires, Argentina. (EA) estebanavigliano@conicet.gov.ar, (AVV) avolpedo@fvet.uba.ar ${ }^{2}$ Instituto Nacional de Investigación y Desarrollo Pesquero (INIDEP). CC 175-7600 Mar del Plata, Argentina. (MBS) mbsaez@inidep.edu. ar, (RR)rrico@inidep.edu.ar 
In the last years, the chemical composition of the otolith has been used to differentiate fish stocks of diverse commercially important species from the southwestern Atlantic Ocean, such as the whitemouth croaker (Micropogonias furnieri) (Volpedo et al., 2007) and longtail hake (Macruronus magellanicus, presentlya junior synonym of Macruronus novaezelandiae) (Schuchert et al., 2010).

The Brazilian flathead, Percophis brasiliensis Quoy \& Gaimard, 1825, is a demersal species that inhabits the southwest Atlantic coastal waters, from $23^{\circ} \mathrm{S}$ (Rio de Janeiro, Brazil) to $47^{\circ} \mathrm{S}$ (Santa Cruz, Argentina) (Barreto et al., 2011). Its distribution is mainly associated with water salinity, with 5- to 8-year-old specimens being more frequently found in high salinity waters $(>33.7 \mathrm{SPU})$ and younger specimens $(<4-7$ years old $)$ in lower salinity waters (approx. 20-30 PSU) resulting from the discharge of different rivers (Barretto, 2007).

In Argentinean waters, $P$. brasiliensis is exploited by multi-species multi-fleet fishery, with commercial capture operations being more frequent in spring and summer, between $34^{\circ}$ and $42^{\circ} \mathrm{S}$ (Rico \& Sáez, 2010). The catch of this species has progressively increased since 1997 (Rico \& Perrotta, 2009), with approximately 8200 tons landed on
Argentinean and Uruguayan coasts during 2012 (Minagri, 2012). However, sustainable fishery management practices have never been implemented, due to the scarce information available for the identification of $P$. brasiliensis stocks. On this regard, Braicovich \& Timi (2008) have suggested the occurrence of three fish stocks in the Argentine-Uruguayan Common Fishing Zone (AUCFZ), El Rincón (ER) and San Matías Gulf (SMG) (Fig. 1), based on the study of parasites. However, this has not been properly validated with other methodologies.

The objective of the present study was to evaluate the simultaneous use of the $\mathrm{Sr}: \mathrm{Ca}$ and $\mathrm{Zn}: \mathrm{Ca}$ ratios of the sagitta otolith as a potential indicator of the habitat of $P$. brasiliensis along a latitudinal gradient in the southwestern Atlantic Ocean $\left(34-42^{\circ} \mathrm{S}\right.$ and $\left.51-67^{\circ} \mathrm{W}\right)$, to reliably identify fish stocks. For this purpose, $\mathrm{Sr}: \mathrm{Ca}$ and $\mathrm{Zn:Ca}$ ratios of the otolith were compared between age groups and three different areas from southwestern Atlantic Ocean (Argentine-Uruguayan Common Fishing Zone, El Rincón and San Matías Gulf).

This information is important for the sustainable exploitation of the species and the development of evaluation models.

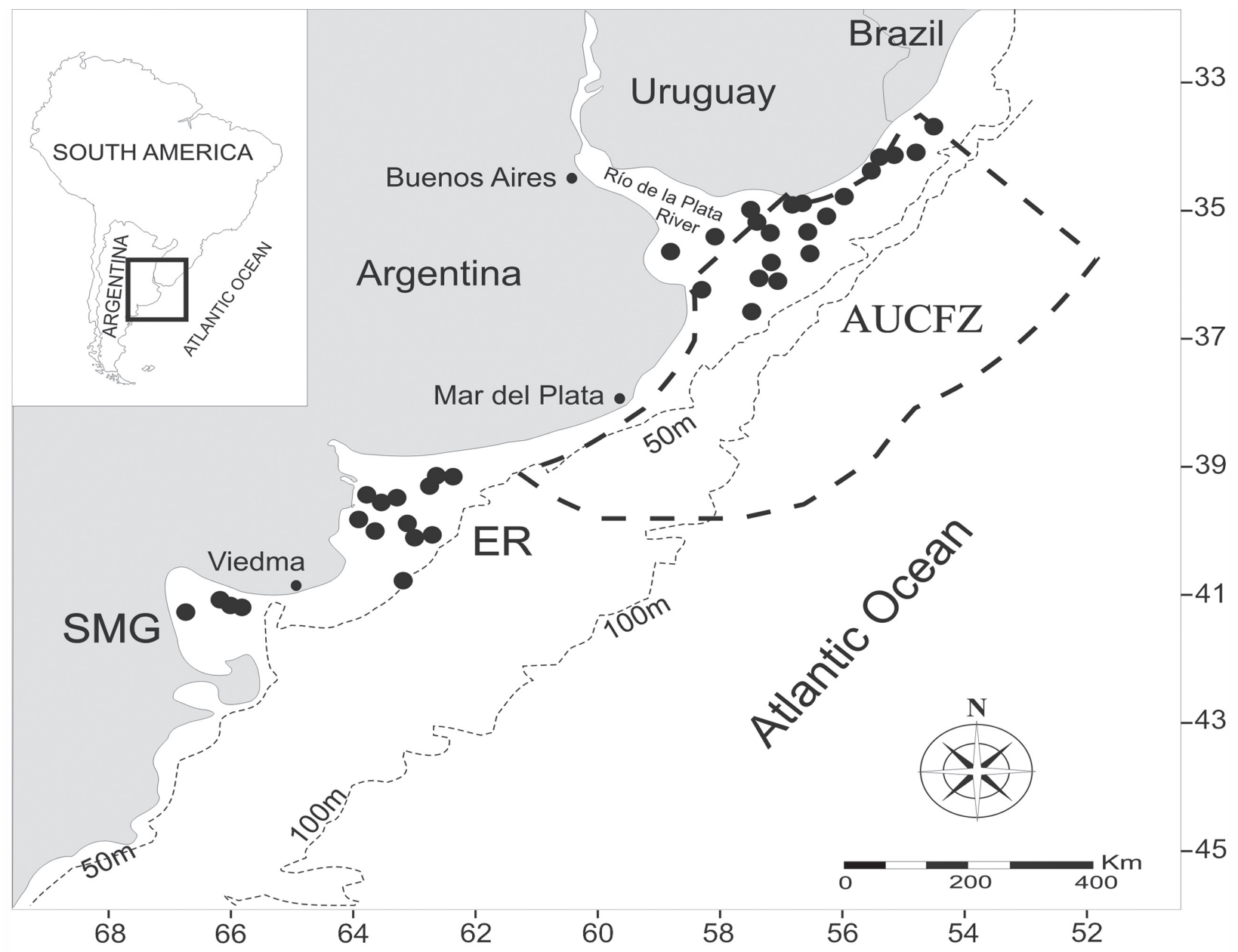

Fig. 1. Sampling sites of the Brazilian flathead, Percophis brasiliensis, in the southwestern Atlantic Ocean. 


\section{Material and Methods}

A sampling campaign was carried out from November to December 2005 (spring) in the Buenos Aires Coastal Ecosystem (ECB), between Argentine-Uruguayan Common Fishing Zone (AUCFZ; $34^{\circ}-38.5^{\circ} \mathrm{S}$ ) and El Rincón (ER; 38.5$42^{\circ} \mathrm{S}$ ) (Fig. 1), over a bathymetric range of 5-54 m (Fig. 1). Another sampling campaign was carried out in November 2009 (spring) between latitudes $40.5^{\circ}-41.5^{\circ} \mathrm{S}$, San Matías Gulf (SMG) (Fig. 1). Brazilian flatheads were caught in 225 bottom trawls that used an Engel trawl (mesh size of $200 \mathrm{~mm}$ in the wings and $120 \mathrm{~mm}$ in the codend, vertical height of $4 \mathrm{~m}$ and horizontal opening of $15 \mathrm{~m}$ ), similar to that used by commercial fishing vessels operating in the San Matías Gulf (SMG). The total number, sex, total length (TL, in centimeters) and total weight (TW, in grams) of the Brazilian flatheads caught in each fishing set were recorded. The sagittae otoliths were removed from each specimen of Percophis brasiliensis (voucher specimen PPGSMB 684, at Instituto Nacional de Investigación y Desarrollo Pesquero (INIDEP) collection, Mar del Plata, Buenos Aires, Argentina); one otolith of the pair was used for age determination and the other for the analysis of $\mathrm{Sr}: \mathrm{Ca}$ and $\mathrm{Zn}: \mathrm{Ca}$ ratios.

Age determination. Sagittae otoliths were embedded in opaque epoxy resin and sectioned transversely through the core to a thickness of $0.5 \mathrm{~mm}$ using a micro-cutter (Maruto MC-201). The opaque bands of these sections were counted by two independent readers under incident and transmitted light using a stereomicroscope (Nikon SMZ 10A) at 40X magnification. The age of each specimen was determined to the nearest year unknowing its length and sex. If the two independent readings differed, then the otolith was discarded. The validation of the periodical occurrence of opaque bands was established from a previous study performed by Barretto et al. (2011); hence, age determination of the specimens was precise and acceptable.

Determination of otolith element:Ca ratios. A total of 143 sagittae otoliths were selected, cleaned with distilled water, dried, weighed to the nearest $0.1 \mathrm{mg}$ in an analytical balance, and then digested with $50 \%$ nitric acid on a sand bath at 400-450 ${ }^{\circ}$ C. Otolith Sr (line: 474.771) and Zn (line: 213.857) concentrations were determined by ICP-OES using a Perkin Elmer Optima 2000 DV optical emission spectrometer (Überlingen, Germany; method EPA, 1994) equipped with a cross-flow nebulizer and a quartz ICP torch. A Perkin-Elmer AS-90 Plus autosampler was used for automated sample handling. All measurements were performed in triplicate (RSD $<4 \%$ ). External calibration was carried out using the atomic spectroscopy standard QCS 21 (Quality Control Standard, Perkin Elmer® Pure, USA). The equipment was cleaned at regular intervals with MilliQ water (Millipore, Saõ Paulo, Brazil) and 10\% nitric acid matrix to prevent sample memory effects. The operating conditions of the ICP-OES equipment are given in Table 1.
Table 1. Operating conditions of the ICP-OES equipment.

$\begin{array}{ll}\text { RF Power } & 1.3 \mathrm{~kW} \\ \text { Plasma gas flow rate } & 15.0 \mathrm{~L} / \mathrm{min} \\ \text { Nebulizer gas flow rate } & 0.80 \mathrm{~L} / \mathrm{min} \\ \text { Auxiliary gas flow rate } & 0.20 \mathrm{~L} / \mathrm{min} \\ \text { Pump flow rate } & 1.2 \mathrm{ml} / \mathrm{min} \\ \text { Delay time } & 20 \mathrm{seg} \\ \text { Flush time } & 20 \mathrm{seg} \\ \text { Number of replicates } & 3\end{array}$

Ca concentration was estimated by the EDTA volumetric method (APHA, 1993). All measurements were performed in triplicate. The digestion and analytical procedures were checked by analysis of Otolith Certified Reference Material for trace elements (FEBS-1, National Research Council, Canada). Replicate analysis of this material showed good accuracy, with the following metal recovery rates: $93 \%$ for $\mathrm{Sr}$ and $110 \%$ for $\mathrm{Ca}$. The element:Ca ratios were expressed in $\mathrm{mmol} \mathrm{mol}{ }^{-1}$ to standardize the concentrations of the elements in relation to $\mathrm{Ca}$.

Statistical Analysis. To avoid possible age effects on the otolith element:Ca ratios, four different age groups were defined (Table 2). An analysis of covariance (ANCOVA) was then used to determine the effect of fish length on the study variables within each age group. Variables that were significantly correlated to fish length were corrected using the common within-group slope (b) for the variable on fish length (e.g., Reist, 1985; Begg et al., 2001; Cardinale et al., 2004; Galley et al., 2006; Burke et al., 2008). Subsequently, the otolith $\mathrm{Sr}: \mathrm{Ca}$ and $\mathrm{Zn}: \mathrm{Ca}$ ratios were compared among the three sampling sites and age groups using the KruskalWallis non-parametric analysis of variance (Sokal \& Rholf, 1995). In addition, the relationship between otolith $\mathrm{Sr}: \mathrm{Ca}$ and $\mathrm{Zn}: \mathrm{Ca}$ ratios was evaluated for each sampling site and age group using discriminant analysis. The analyses were performed with the statistical software InfoStat ${ }^{\mathbb{Q}}$.

Table 2. Number of specimens (N) of Percophis brasiliensis per age group and sampling site. Argentine-Uruguayan Common Fishing Zone (AUCFZ), El Rincón (ER), San Matías Gulf (SMG).

\begin{tabular}{llll}
\hline Age & AUCFZ & ER & SMG \\
\hline $3-5$ & 31 & 21 & 7 \\
$6-7$ & 12 & 8 & 10 \\
$8-9$ & 10 & 9 & 19 \\
$10-11$ & - & 6 & 10 \\
\hline
\end{tabular}

\section{Results}

Otolith Sr:Ca and $\mathrm{Zn:Ca}$ ratios. For all age groups, the otolith $\mathrm{Sr}: \mathrm{Ca}$ ratio was similar $(\mathrm{p}>0.05)$ while the otolith $\mathrm{Zn}: \mathrm{Ca}$ ratio was significantly different between fish from AUCFZ and fish from ER and SMG ( $<<0.05$; Table 3). 
Table 3. Otolith $\mathrm{Sr}: \mathrm{Ca}$ and $\mathrm{Zn}: \mathrm{Ca}$ ratios (mean \pm standard deviation) for Percophis brasiliensis from the ArgentineUruguayan Common Fishing Zone (AUCFZ), El Rincón (ER) and San Matías Gulf (SMG), within each age group. Different letters indicate statistical significance among sampling sites for each age group $(\mathrm{p}<0.05)$.

\begin{tabular}{cccc}
\hline \multicolumn{4}{c}{ Sr:Ca $\left(\mathrm{mmol} \mathrm{mol}^{-1}\right)$} \\
\hline Age & AUCFZ & El Rincón & SMG \\
\hline $3-5$ & $2.16 \pm 0.41^{\mathrm{a}}$ & $2.27 \pm 0.28^{\mathrm{a}}$ & $2.07 \pm 0.33^{\mathrm{a}}$ \\
$6-7$ & $2.39 \pm 0.31^{\mathrm{a}}$ & $2.80 \pm 0.40^{\mathrm{a}}$ & $2.29 \pm 0.70^{\mathrm{a}}$ \\
$8-9$ & $3.07 \pm 0.36^{\mathrm{a}}$ & $3.30 \pm 0.96^{\mathrm{a}}$ & $3.25 \pm 1.39^{\mathrm{a}}$ \\
$10-11$ & - & $2.80 \pm 0.29^{\mathrm{a}}$ & $2.92 \pm 0.47^{\mathrm{a}}$ \\
\hline \multicolumn{4}{c}{$\mathrm{Zn}: \mathrm{Ca}\left(\mathrm{mmol} \mathrm{mol}^{-1}\right)$} \\
\hline $3-5$ & $0.45 \pm 0.38^{\mathrm{a}}$ & $0.25 \pm 0.11^{\mathrm{b}}$ & $0.27 \pm 0.29^{\mathrm{b}}$ \\
$6-7$ & $0.35 \pm 0.18^{\mathrm{a}}$ & $0.14 \pm 0.11^{\mathrm{b}}$ & $0.18 \pm 0.13^{\mathrm{b}}$ \\
$8-9$ & $0.25 \pm 0.09^{\mathrm{a}}$ & $0.14 \pm 0.07^{\mathrm{b}}$ & $0.13 \pm 0.09^{\mathrm{b}}$ \\
$10-11$ & - & $0.15 \pm 0.04^{\mathrm{a}}$ & $0.11 \pm 0.06^{\mathrm{a}}$ \\
\hline
\end{tabular}

The relationship between the otolith $\mathrm{Sr}: \mathrm{Ca}$ and $\mathrm{Zn}: \mathrm{Ca}$ ratio and fish age, together with the significance levels from the Kruskal-Wallis test, are shown in Fig. 2a,b. The otolith $\mathrm{Sr}: \mathrm{Ca}$ ratio significantly increased with age in the three sampling sites (Fig. 2). The otolith $\mathrm{Zn}: \mathrm{Ca}$ ratio decreased with age in all the study sites, but this was only statistical significant for ER (Fig. 2).
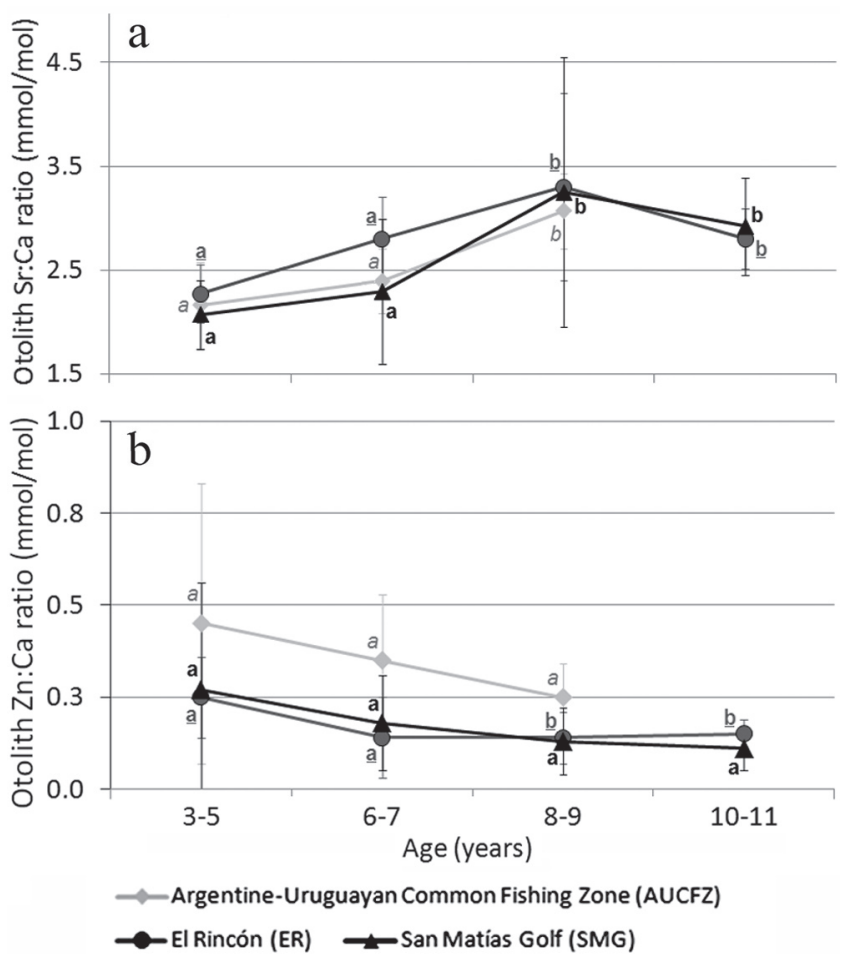

Fig. 2. Variation of $\mathrm{Sr}: \mathrm{Ca}(\mathrm{a})$ and $\mathrm{Zn}: \mathrm{Ca}$ (b) ratios of Percophis brasiliensis separated by age for the three sampling sites. Different letters indicate statistical significant differences among age groups (years) for each sampling site $(\mathrm{p}<0.05)$.
Dispersion analysis between the otolith $\mathrm{Sr}$ :Ca and $\mathrm{Zn}$ :Ca ratios. In the dispersion analysis, all age groups data for ER and SMG tended to cluster at low values of the otolith $\mathrm{Zn}: \mathrm{Ca}$ ratio (Fig. 3a-d), while data for AUCFZ tended to scatter at high values of this ratio (Fig. 3a-c).
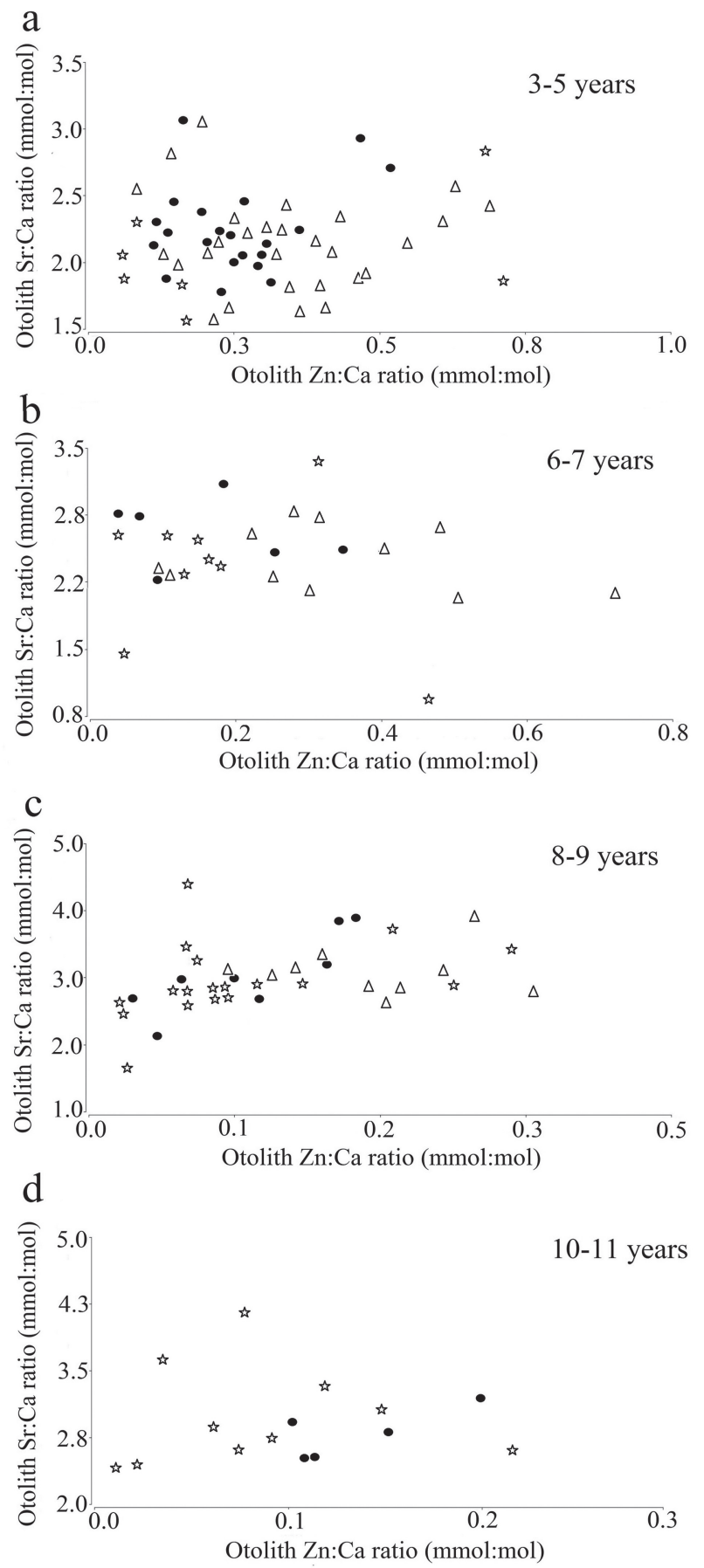

Fig. 3. Relationship between otolith $\mathrm{Sr}: \mathrm{Ca}$ and $\mathrm{Zn}: \mathrm{Ca}$ ratios $\left(\mathrm{mmol} \mathrm{mol}{ }^{-1}\right)$ for Percophis brasiliensis from three areas. Data for ER and SMG tended to cluster, while data for AUCFZ tended to disperse. Separation of data of AUCFZ and ER-SMG is observed. Triangles: Argentine-Uruguayan Common Fishing Zone (AUCFZ), stars: San Matías Gulf (SMG) and black circles: El Rincón (ER). 
Discriminant analysis. The discriminant analysis showed an association between otolith $\mathrm{Sr}: \mathrm{Ca}$ and $\mathrm{Zn}: \mathrm{Ca}$ ratios in ER-SMG for the age groups 3-5, 6-7 and 8-9 years (Fig. $4 \mathrm{a}-\mathrm{c})$. For all cases, the first axis explained most of the variability in the data, being the most important variable in this axis, $\mathrm{Zn}$ :Ca ratio (Table 4). No fish from the age group 10-11 years was captured in AUCFZ.

Table 4. Variability explained by the first canonical axis ( $\%$ FCA) and eigenvalues from the discriminant analysis of otolith microchemistry (Figure 4, a-d). Letters in brackets indicate the reference to Fig. 4 (a-d).

\begin{tabular}{lllll}
\hline \multicolumn{5}{c}{ Age (years) } \\
\hline \multirow{2}{*}{ \% FCA } & $3-5(\mathrm{a})$ & $6-7(\mathrm{~b})$ & $8-9(\mathrm{c})$ & $10-11(\mathrm{~d})$ \\
\cline { 2 - 5 } Sr:Ca eigenvalues & 82.78 & 69.05 & 98.69 & 99.99 \\
Zn:Ca eigenvalues & -0.94 & -0.4 & -0.45 & -0.53 \\
\hline
\end{tabular}

\section{Discussion}

The Brazilian flathead is a marine species that inhabits areas with different salinity levels throughout its life cycle. Juveniles and young adults $(<4-7$ years old) are distributed in relatively low salinity waters (20-30 SPU), while adults ( $>5-8$ years old) are found in higher salinity waters (Barretto, 2007). In AUCFZ, this parameter ranged between 22 and 33 SPU due to the in-flow of less salty waters from the freshwater plume of the Río de la Plata (Marrari et al., 2004), which extends from 70 to $200 \mathrm{~km}$ into the open sea, depending on the river flow (Guerrero et al., 1997). Waters from of ER are influenced by the discharge of the Negro River and Colorado River (Guerrero et al., 1997). On this basis, the otolith Sr:Ca ratio was expected to vary along the study region. However, this ratio was similar among sampling sites for all age groups (Table 3). Despite the memory effect that would have older samples due to the total digestion of otoliths, a positive relationship was observed between the Sr:Ca ratio and fish age (Fig. 2). This is consistent with the movement of 4- to 7-year-old fish toward areas of higher salinity. However, it may also be related to changes in the rate of Sr incorporation into the otoliths due to physiological and ontogenetic factors. Brown \& Severin (2009) indicated that the water $\mathrm{Sr}: \mathrm{Ca}$ ratio was more homogeneous in marine environments than in freshwater or brackish environments. Therefore, the variation in the otolith Sr:Ca ratio in marine species is more likely due to physiological factors, rather than the result of the exposure to heterogeneous environments (Campana, 1999; Brown \& Severin, 2009). Specific studies on $\mathrm{Sr}$ incorporation into the otoliths of $P$. brasiliensis are required to explain present results.

Coastal areas show great chemical heterogeneity due to upwelling, fluvial, and anthropogenic inputs, but often the pollutants that would contribute to such geographic variation in the concentration of $\mathrm{Zn}$ (Sturrock et al., 2012). $\mathrm{Zn}$ was proposed as an indicator of habitat because its incorporation into the otoliths is influenced by the diet of fish (Ranaldi \& Gagnon, 2008). The significantly different otolith $\mathrm{Zn}: \mathrm{Ca}$ ratio between Brazilian flatheads from AUCFZ and ER-SMG, both of which correspond to the latitudinal extremes of the study region (Table 3), may suggest that they belong to different fish stocks. The otolith $\mathrm{Zn}: \mathrm{Ca}$ ratio of fish from ER, located in the middle area of the study region, was significantly different from that of fish collected in AUCFZ but similar to that of fish from SMG (Table 3). In addition, a negative relationship was observed between this ratio and fish age. Considering that the otolith $\mathrm{Zn}: \mathrm{Ca}$ ratio tend to decrease with water salinity (McCulloch et al., 2005), present results are consistent with the movement of older specimens to areas of high salinity, as previously reported by Barretto (2007).

On the other hand, an association was found between the otolith $\mathrm{Sr}: \mathrm{Ca}$ and $\mathrm{Zn}: \mathrm{Ca}$ ratios for fish groups from ER and SMG, with these groups being separated from the one located in AUCFZ (Fig. 3). This may be the result of interactions between Brazilian flatheads from ER and SMG, with both groups possibly constituting a stock. The discriminant analysis showed a separation between AUCFZ and ER-SMG for the age groups 3-5, 6-7 and 8-9 years, which was mainly explained by the otolith $\mathrm{Zn}: \mathrm{Ca}$ ratio (Fig. 4).

The results of the present study may suggest the potential occurrence of at least two fish stocks of $P$. brasiliensis in the southwestern Atlantic Ocean, between the latitudes 34$42^{\circ} \mathrm{S}$ and $51-67^{\circ} \mathrm{W}$. One of them may be found in the north of the study region (AUCFZ, coast of Uruguay), while the other may be located in the south of this region (ER: $39^{\circ}-$ $41^{\circ} \mathrm{S}$ and $62^{\circ}-64^{\circ} \mathrm{W}$ and SMG: $41^{\circ} \mathrm{S}$ and $63^{\circ} \mathrm{W}$ ).

The occurrence of three different stocks of $P$. brasiliensis in the southwestern Atlantic Ocean has already been suggested by Braicovich \& Timi (2008), based on the analysis of parasite composition. According to these authors the stocks were located in AUCFZ, ER and SMG, respectively. The simultaneous use of the otolith $\mathrm{Sr}: \mathrm{Ca}$ and $\mathrm{Zn}: \mathrm{Ca}$ ratios did not allow us to differentiate populations from ER and SMG, but it allowed us to discriminate them from the population located in AUCFZ. Even though this result does not completely agree with those reported by Braicovich \& Timi (2008), it further supports the occurrence of different fish stocks. These populations may be divided, at least in part, by marine fronts. A high salinity water tongue from the SMG is located to the east of the relatively diluted waters of ER, and forms a north-south front $\left(39^{\circ} \mathrm{S}\right)$ that induces seawater recirculation (Piola \& Rivas, 1997). Previous studies on adult fishes and ichthyoplankton have shown that this is an important breeding area for P. brasiliensis (Acha et al., 2012), where seawater recirculation facilitates the retention of eggs and larvae and the life cycle of the species is completed (Rodrigues et al., 2010; Acha et al., 2012). Hence, the low interaction between fish groups from AUCFZ and ER-SMG may be explained by the presence of a marine front. 

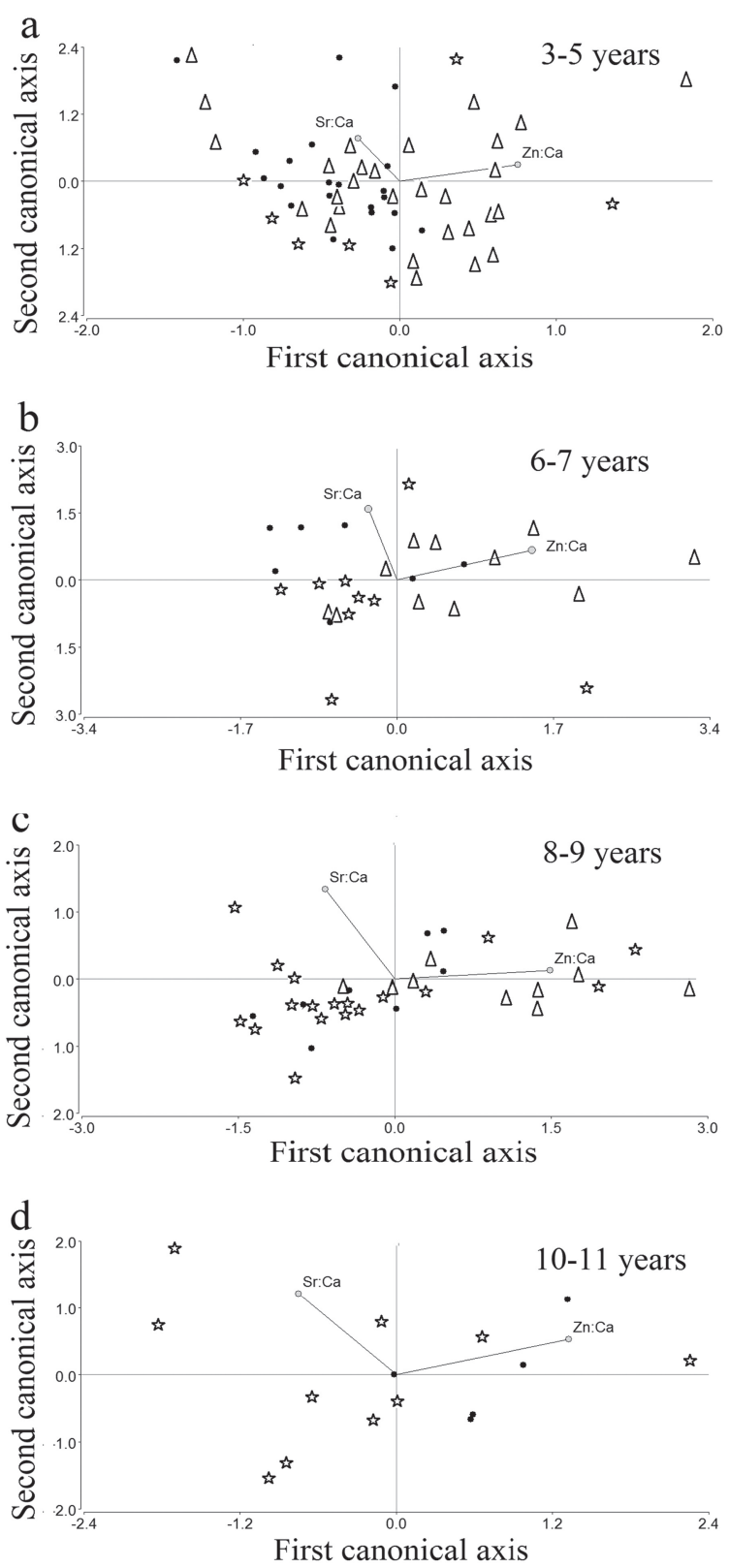

Fig. 4. Discriminant analysis of the otolith $\mathrm{Sr}: \mathrm{Ca}$ and $\mathrm{Zn}: \mathrm{Ca}$ ratios for Percophis brasiliensis. Plot of the first two discriminant functions for each age group (a-d). An association was observed between data for ER and SMG, which were separated from data for AUCFZ. Triangles: ArgentineUruguayan Common Fishing Zone (AUCFZ), stars: San Matías Gulf (SMG) and black circles: El Rincón (ER).

The simultaneous use of the $\mathrm{Sr}: \mathrm{Ca}$ and $\mathrm{Zn}: \mathrm{Ca}$ ratios of the sagitta otolith is a potential indicator of the habitat of $P$. brasiliensis along a latitudinal gradient in the southwestern Atlantic Ocean. The otolith $\mathrm{Sr}$ Ca ratio was associated with fish age and could be used as an indicator of habitat. However, this ratio did not allow differentiating stocks of $P$. brasiliensis. The otolith $\mathrm{Zn}: \mathrm{Ca}$ ratio tended to decrease with age and allowed the differentiation of two fish groups (AUCFZ and ER-SMG). For this reason, it could also be considered as a potential indicator of habitat. Based on these results, the incorporation of other otolith ratios (e.g., $\mathrm{Ba}: \mathrm{Ca}$, $\mathrm{Mn}: \mathrm{Ca}, \mathrm{Mg}: \mathrm{Ca}, \mathrm{Li}: \mathrm{Ca}$ ) to the analysis is suggested in order to complement the study of potential habitat indicators for the Brazilian flathead. This may validate the identification of fish stocks, thus contributing to the sustainable management of that resource in the southwestern Atlantic Ocean.

\section{Acknowledgments}

We are grateful to "Programa Especies Demersales Costeras" from INIDEP (Argentina) and IBMPAS, Universidad Nacional del Comahue and Dr. R. González for the samples collected during the cruise REDE 2009, Universidad de Buenos Aires (UBACYT 20620110100007), CONICET (PIP 112-20120100543CO) and ANPCyT (PICT2010-1372). This paper corresponds to INIDEP Contribution n. ${ }^{\circ} 074$.

\section{References}

Acha, E. M., M. Orduna, K. Rodrigues, M. I. Militelli \& M. Braverman. 2012. Caracterización de la zona de "El Rincón" (Provincia de Buenos Aires) como área de reproducción de peces costeros. Revista de Investigación y Desarrollo Pesquero, 21: 31-43.

APHA. 1993. Standard Methods for the Examination of Water and Wastes. Washington, D.C., American Public Health Association.

Avigliano, E., \& A. V. Volpedo. 2013. Use of otolith strontium: calcium ratio as indicator of seasonal displacements of the silverside (Odontesthes bonariensis) in a freshwater-marine environment. Marine and Freshwater Research, 64: 746-751.

Avigliano, E., C. Riaños Martinez \& A. V. Volpedo. 2013. Combined use of otolith microchemistry and morphometry as indicators of the habitat of the silverside (Odontesthes bonariensis) in a freshwater-estuarine environment. Fisheries Reseach, 149: 55-60.

Barreto, A. C. 2007. Influencia ambiental en la distribución espacial de las clases de edad de pez palo (Percophis brasiliensis) en el Sistema Costero del Atlántico Sudoccidental $\left(34^{\circ}-41^{\circ}\right.$ S). Unpublished Ph.D. Dissertation, Universidad de Buenos Aires, Argentina, 43p.

Barretto, A. C., M. B. Sáez, M. R. Rico \& A. J. Jaureguizar. 2011. Age determination, validation, and growth of Brazilian flathead (Percophis brasiliensis) from the southwest Atlantic coastal waters $\left(34^{\circ}-41^{\circ} \mathrm{S}\right)$. Latin American Journal of Aquatic Research, 39: 297-305.

Begg, G. A., W. J. Overholtz \& N. J. Munroe. 2001. The use of internal otolith morphometrics for identification of haddock (Melanogrammus aeglefinus) stocks on Georges Bank. Fishery Bulletin, 99: 1-14.

Braicovich, P. E. \& J. T. Timi. 2008. Parasites as biological tags for stock discrimination of the Brazilian flathead in the southwest Atlantic. Journal of Fish Biology, 73: 557-571.

Brown, R. J. \& K. P. Severin. 2009. Otolith chemistry analyses indicate that water $\mathrm{Sr}: \mathrm{Ca}$ is the primary factor influencing otolith $\mathrm{Sr}: \mathrm{Ca}$ for freshwater and diadromous fish but not for marine fish. Canadian Journal of Fisheries and Aquatic Sciences, 66: 1790-1808. 
Burke N., D. Brophy \& P. A. King. 2008. Otolith shape analysis: its application for discriminating between stocks of Irish Sea and Celtic Sea herring (Clupea harengus) in the Irish Sea. ICES Journal of Marine Science, 65: 1670-1675.

Campana, S. E. 1999. Chemistry and composition of fish otoliths: pathways, mechanisms and applications. Marine Ecology Progress Series, 188: 263-297.

Cardinale, M., P. Doering-Arjes, M. Kastowsky \& H. Mosegaard. 2004. Effects of sex, stock, and environment on the shape of known-age Atlantic cod (Gadus morhua) otoliths. Canadian Journal of Fisheries and Aquatic Sciences, 61: 158-167.

EPA. 1994. Methods for the Determination of Metals in Environmental Samples. Supplement 1. Ohio.

Galley, E. A., P. J. Wright \& F. M. Gibb. 2006. Combined methods of otolith shape analysis improve identification of spawning areas of Atlantic cod. ICES Journal of Marine Science, 63: 1710-1717.

Guerrero, R.A., E. M. Acha, M. B. Framiñan \& C. A. Lasta. 1997. Physical oceanography of the Rio de la Plata estuary, Argentina. Continental Shelf Research, 17: 727-742.

Kraus, R. T. \& E. R. Secor. 2004. Incorporation of strontium into otoliths of an estuarine fish. Journal of Experimental Marine Biology and Ecology, 302: 85-106.

Marrari, M., M. D. Viñas, P. Martos \& D. Hernández. 2004. Spatial patterns of mesozooplankton distribution in the Southwestern Atlantic Ocean $\left(34^{\circ}-41^{\circ} \mathrm{S}\right)$ during austral spring: relationship with the hydrographic conditions. Journal of Marine Science, 61: 667-679.

McCulloch, M., M. Cappo, J. Aumend \& W. Müller. 2005. Tracing the life history of individual barramundi using laser ablation MC-ICP-MS Sr-isotopic and Sr/Ba ratios in otoliths. Marine and Freshwater Research, 56: 637-644.

Minagri, 2012. Ministerio de Agricultura y Pesca de la Nación Argentina. Available from: http://www.minagri. gob.ar/site/pesca/pesca_maritima/02-desembarques/anio. php?anio=2012 (27 December 2012).

Piola, A. R. \& A. L. Rivas. 1997. Masas de agua en la plataforma continental. Pp. 119-132. In: Boschi, E. (Ed.). El Mar Argentino y sus Recursos Pesqueros. Antecedentes Históricos de las Exploraciones en el Mar y las Características Ambientales. Mar del Plata, Argentina, El Mar Argentino y sus Recursos Pesqueros. v.1.

Popper, A. N. \& L. Zhongmin. 2000. Structure-function relationship in fish otolith organs. Fisheries Research, 46: 15-25.

Ranaldi, M. M. \& M. M. Gagnon. 2008. Zinc incorporation in the otoliths of juvenile pink snapper (Pagrus auratus Forster): The influence of dietary versus waterborne sources. Journal of Experimental Marine Biology and Ecology, 360: 56-62.

Reist, J. D. 1985. An empirical evaluation of several univariate methods that adjust for size variation in morphometric data. Canadian Journal of Zoology, 63: 1429-1439.

Rico, M. R. \& M. B. Sáez. 2010. Análisis de la estructura de tallas; determinación de la edad, validación y crecimiento de pez palo (Percophis brasiliensis) a partir de muestras del desembarque comercial en el puerto de Mar del Plata. Informe Técnico INIDEP, 85: 1-20.
Rico, M. R. \& R. G. Perrotta. 2009. Evolución reciente de la captura por unidad de esfuerzo (1993-2004) y de las tallas medias (1993-2005) del pez palo (Percophis brasiliensis) en el litoral marítimo entre $34^{\circ} \mathrm{S}$ y $42^{\circ} \mathrm{S}$. Informe Técnico INIDEP, 73: 1-21.

Rodrigues, K. A., M. R. Rico, M. I. Militelli, P. Osovnikar \& M. Maggioni. 2010. Parámetros reproductivos y distribución de las hembras de pez palo (Percophis brasiliensis) y lenguado (Paralichthys patagonicus) en el Golfo San Matías. Informe Técnico INIDEP, 65: 1-20.

Schuchert, P. C., I. Alexander, R. Arkhipkin \& A. E. Koenig. 2010. Traveling around Cape Horn: Otolith chemistry reveals a mixed stock of Patagonian hoki with separate Atlantic and Pacific spawning grounds. Fisheries Research, 102: 80-86.

Secor, D. H., A. Henderson-Arzapalob \& P. M. Piccoli. 1995. Can otolith microchemistry chart patterns of migration and habitat utilization in anadromous fishes? Journal of Experimental Marine Biology and Ecology, 192: 15-33.

Sokal, R. R. \& F. J. Rohlf. 1995. Biometry: The Principles and Practice of Statistics in Biological Research. $3^{\text {rd }}$ ed. Local, W. H. Freeman.

Sturrock, A. M., C. N. Trueman, A. M. Darnaude \& E. Hunter. 2012. Can otolith elemental chemistry retrospectively track migrations in fully marine fishes. Journal of Fish Biology, 81: 766-795.

Tabouret, H., G. Bareille, F. Clverie, C. Pecheyran, P. Prouzet \& O. F. Donard. 2010. Simultaneous use of strontium:calcium and barium:calcium ratios in otoliths as markers of habitat: application to the European eel (Anguilla anguilla) in Adour Basin, South West France. Marine Environmental Research, 70: $35-45$.

Volpedo, A. V., P. Miretzky \& A. Fernández Cirelli. 2007. Stocks pesqueros de Cynoscion guatucupa y Micropogonias furnieri de la costa atlántica de Sudamérica: comparación entre métodos de identificación. Memoria de la Fundación La Salle de Ciencias Naturales, 165: 115-130.

Wells, B. K., B. E. Rieman, J. L. Clayton, D. L. Horan \& C. M. Jones. 2003. Relationships between water, otoliths, and scale chemistries of Westslope cutthroat trout from the Coeur d'Alene River, Idaho: the potential application of hard-part chemistry to describe movements in freshwater. Transactions of the American Fisheries Society, 132: 409-424.

Zlokovitz, E. R., D. H. Secor \& P. M. Piccoli. 2003. Patterns of migration in Hudson River striped bass as determined by otolith microchemistry. Fisheries Research, 63: 245-259.

Submitted December 30, 2013 Accepted October 6, 2014 by Adalberto Val Published March 31, 2015 
